\title{
Assessment of the future role of some energy sources by higher education students in Hungary
}

\author{
LÁSZLÓ BERÉNYI \\ Institute of Management Science \\ University of Miskolc \\ H3515 Miskolc-Egyetemváros \\ HUNGARY \\ NIKOLETT DEUTSCH \\ Institute for the Development of Enterprises \\ Budapest Corvinus University \\ H1093 Budapest, Fővám Square 8. \\ HUNGARY
}

\begin{abstract}
Serving the ever-increasing energy demand of the world by preventing the excessive deterioration of the environment requires the continuous development of energy technologies. Both renewable and nuclear power are reasonable alternatives to fossil sources. Beyond the engineering and economic issues, the social acceptance of the technologies is an essential factor. Recent literature pays growing attention to learning students' attitudes to renewable energy and sustainability since they are the future users and the decision-makers. Targeted actions in the field need thorough investigations about the opinions, attitudes, and knowledge level of the new generations. This paper contributes to a better understanding of higher education students' approaches to renewable and nuclear energy in Hungary by a voluntary online survey on evaluation and ranking the energy sources. The research sample includes 328 business, engineering, and state science students from various Hungarian universities. The results show the respondents are optimistic about favorable future changes in the utilization of renewable energies, but the opinions are scattered. Using the energy sources, sparingly seems to be more acceptable by the respondents than making financial sacrifices for a greener solution. The results of the pairwise comparison pointed out that solar power and wind power are considered decisive and acceptable sources. There is a general distrust of nuclear energy among the respondents. The analysis did not find significant differences between the responses of students from different faculties. The evaluations confirm a positive approach to sustainability and the particular emphasis on solar power. The result shows the need for knowledge formation that the assessment of the future role is not in line with the professional opinion and the national strategy.
\end{abstract}

Key-Words: - renewable energy sources, nuclear power, social acceptance, higher education, student opinion, pairwise comparison

Received: May 28, 2020. Revised: October 9, 2020. Accepted: October 13, 2020. Published: October 14, 2020.

\section{Introduction}

The energy dependence of humankind is evident, but the solutions for meeting the needs are continuously developed. Moreover, the new technologies must serve an increasing demand [1]. Beyond technical limitations, social requirements, and policies also influence future directions. The umbrella of sustainability [2] offers a comprehensive framework for coordinated development actions. Climateneutrality [3] [4] and the reduction of $\mathrm{CO}_{2}$ emission [5] require an increase in using renewable energy sources [6]. Both the EU and the Hungarian government emphasize the importance of renewables
[3] [7]. Renewable energy is instrumental to the success of Sustainable Development Goals [8].

There are alternatives available to fossil energy sources. Both renewable and nuclear energy can be considered [9], but some limitations slow down their spread. Local availability or relative high investment cost is the most insane enemy of renewables, while nuclear accidents and other faults [10] [11] as well as uncertain waste management solutions [12] [13] are warning signs against nuclear power.

Although developing new energy technologies is a hard engineering challenge, besides the technical feasibility and related economic interest, the social 
acceptance of the new technologies [14] [15] [16] is critical to success. Gil Vera [17] confirmed that the factors of use, utility, government support, training, adaptability, and perception of the acceptance of renewable energy sources influence the construct. Moreover, the system structure of the distribution may affect usability and acceptance [18]. Relevant literature confirms the authors' opinion [14] [19] [20] [20] [22] that an extensive multicriteria evaluation must be applied for exploring the factors of acceptance by considering the local issues [23].

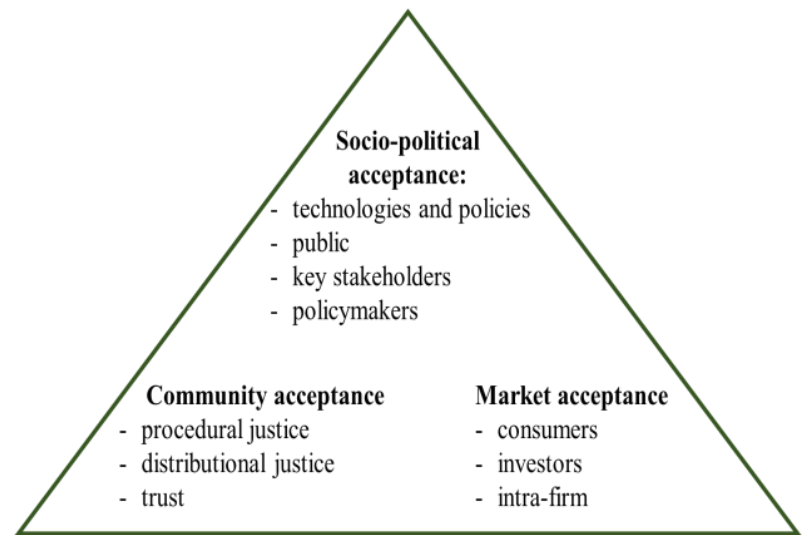

Fig.1. Social acceptance of renewable energy innovation [21]

Social acceptance includes market, sociopolitical, and community level acceptance of the technology (Fig.1). Behind these, an essential component of social acceptance is the time-factor, which appears in many ways. Collecting experience or learning the long-term effects of a new technology needs time. Resistance to change is a general factor; therefore, shaping the new generations' consciousness with even less prejudice seems expedient. Reviewing the students' approach to renewable and nuclear energy provides a strategically important knowledge base in the field.

Recent literature gives a high emphasis to the students' approach to energy issues directly or integrated into sustainability (see e.g. [24] [25] [26] [27] [28] [29]). Common elements of the conclusions of the studies are that:

- there is a positive approach to enhancing sustainability,

- the students are aware of the importance of renewables,

- solar power has a very positive image,

- the lack of detailed knowledge about renewables and energy calls for action.

This paper summarizes an experiment among Hungarian higher education students for analyzing their opinion about renewable and nuclear energy sources. Assuming that a distortion of the responses can be expected due to the high emphasis on the topic, a pairwise comparison method is applied.

\section{Problem Formulation}

The goal of $20 \%$ use of renewables by 2020 in the EU [30] received much attention and provided a framework for technological development programs. The share of renewables in gross final energy consumption shows an increasing tendency in recent years (Fig.2). The Hungarian trend shows a significant catching up by 2013 , then decline. Following the EU directions, a boost-up of the development is required.

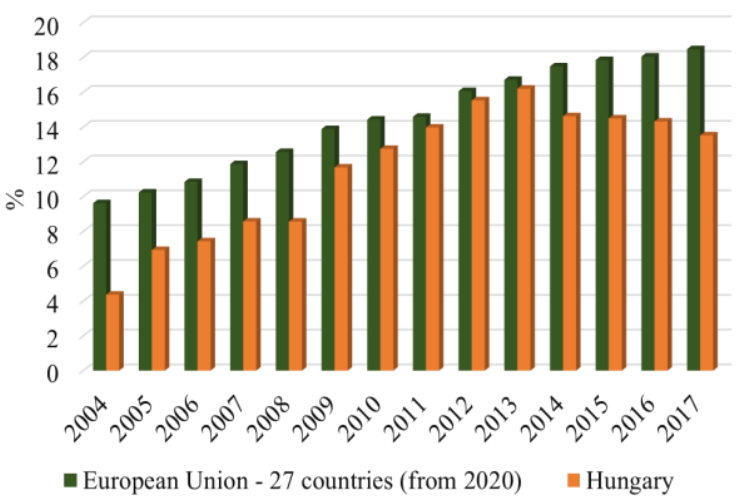

Fig.2. Share of renewable energy in gross final energy consumption (\%) [31]

The Hungarian Central Statistical Office maintains a database of the share of renewables in electric power generation between 2000 and 2018 [32]. The contribution of renewables has gradually increased from $0.7 \%$ in 2000 to $8.1 \%$ in 2018 . The production of primary renewable energy sources by energy source enter the data in PJ [33]. Biofuels, biomass, and renewable part of communal waste represent the majority of energy production (Fig.3). Other energy sources (Fig.4) represent ca. 15\% of these sources.

Geothermal energy is the most representative energy source in Fig.4. Biogas and solar energy show a relevant increase in recent years. Wind power prediction increased from 2012, but due to a change in the licensing system in Hungary, it fell to $2.2 \mathrm{PJ}$ in 2018. However, wind energy is an effective, efficient, and economical way of power generation [34] [35]. 


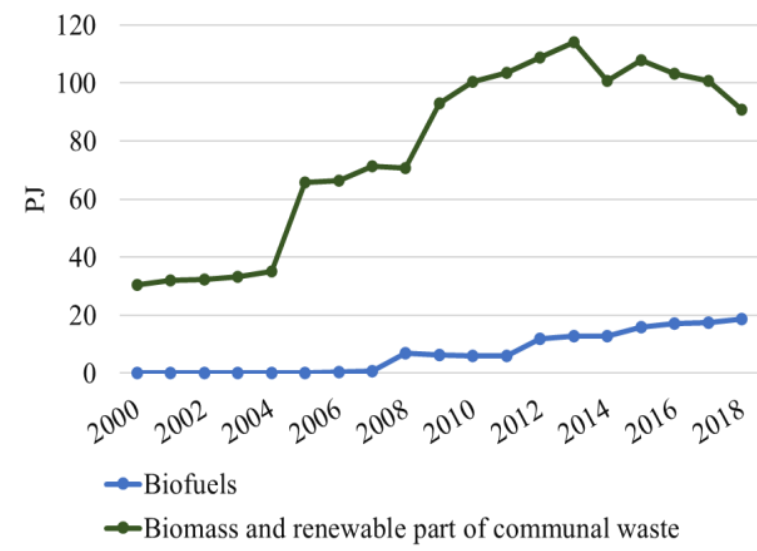

Fig.3. Production of primary energy sources in Hungary - biofuels and biomass [33]

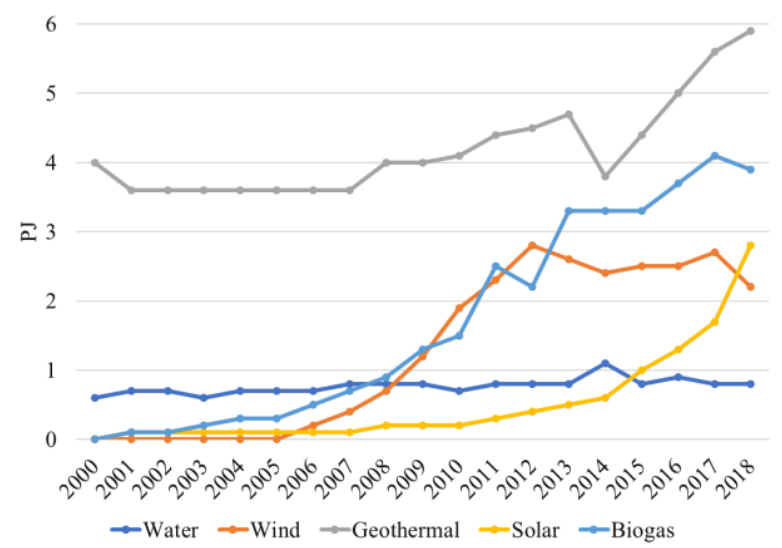

Fig.4. Production of primary energy sources in Hungary - without biofuels and biomass [33]

Of course, customers rarely see precisely the source of the energy they use every day, and other factors can influence the judgment of the energy sources. Solar technology is widely emphasized. Although the access and efficiency of photovoltaic energy are volatile [36], it is widespread, and there are several residential and personal applications available. On the other side, nuclear energy has several risks that lead to social resistance. However, $15.6 \%$ of the primer energy use is provided by nuclear energy, while renewables give $11.8 \%$, and fossils give $42.3 \%$.

Strategic decisions in energy policy require a multicriteria evaluation since the investments and the systems affect the whole society, including several stakeholder groups with their own interest. Beyond the technological or economic cost and benefits, taking different corporate, public, and private interests together into account is required to successfully implement the energy strategy. It is inevitable to form a comprehensive picture of the future possibilities and the influencing factors of technological acceptance, and local investigations are needed in the field. According to the new solutions' acceptance, particular attention should be paid to the attitudes and opinions as part of this analysis. Our research contributes to this challenge among higher education students who can soon play a decisionmaking role in a corporation or the government.

\section{Research Design}

\subsection{Research goal}

Understanding the non-professional opinions about power generation and energy sources has several benefits. Improved social acceptance of technology may reduce hostile actions against the implementations that lead to resource savings. Moreover, by finding the gaps in the knowledge and the resistance factors, targeted action measures can be justified on education or public information.

Higher education students are the shapers of the future as corporate managers and policymakers. Their opinions, attitudes, and knowledge are essential in the further development of power generation.

The research goal is to study the opinions about the economic return, environmentally friendly nature, and the future role of renewable energy sources.

Assuming that different faculties deal with the field's technological and social aspects in different depths, diverse evaluations are expected. Formulated as a hypothesis, the evaluation of renewable and nuclear energy sources differs between business, engineering, and state science students. The results focus on the opinion of Hungarian higher education students.

\subsection{Survey design}

The research uses a voluntary online survey designed for anonymous data collection among nonprofessionals. The survey asks the respondents to evaluate some characteristics of the following energy sources by pairwise comparison:

- biomass,

- nuclear,

- solar,

- hydro, and

- wind power.

The perspectives include the future role of the given energy source, its economic aspects (return), and environmentally friendly nature:

- Return: Which power generation technology has the highest financial return on investment?

- Environmentally friendly nature: Which technology is environmentally friendly overall? 
- Future: Which power generation technology will be the most decisive in the coming decades?

According to the assessment of the opinions on future directions, the questionnaire also includes scale rated questions as follows:

- How do you think we currently use renewable energy sources compared to other European countries? (current use)

- Do you think people would pay more for energy if it were definitely from a 'green' source? (pay for green energy)

- How much do you agree with the statement that people are increasingly striving to save energy in their everyday lives? (striving to save)

- How do you think we will use renewable energy sources compared to other European countries in $10-15$ years? (future use)

\subsection{Methods of analysis}

The items of the pairwise comparisons are optimally ordered with the Ross-method [37]. Beyond the distribution of rank-sums, the results include:

- the personal level of consistency,

- the rank orders by Guilford-method [38],

- the group level consensus of the responses.

The personal level of consistency $(\mathrm{K})$ describes whether the preference order of the respondent is clear $(0 \leq \mathrm{K} \leq 1, \mathrm{~K}=0$ is the complete absence of consistency, $\mathrm{K}=1$ is a complete consistency), further analyses are limited to the consistent responses. The group-level preference orders are presented on an interval-scale between 0 and 100. Scattering of opinions is described by a corrected value of Kendall's coefficient of concordance for pairwise comparison $(v)$ that shows the group level consensus between $0 \%$ and $100 \%$.

Besides, the scale rated questions allow the calculation of correlation (Spearman's Rho method for ordinal scale) and the non-parametric analysis of variance (Kruskal-Wallis $\mathrm{H}$ ).

The calculations follow the guidance of [38] [39]. Data processing was supported by IBM SPSS 25 and Microsoft Excel.

\subsection{Research sample and limitations}

Hungarian higher education students from various universities and faculties are asked to form their opinion about the future role of energy sources. The data collection period covers 2019 and 2020. The research sample includes business, engineering, and state science students. Since the dataset is not representative and business students are overrepresented in it, among them, a random selection was applied. The results of this paper are based on the evaluation of 121 business, 89 engineering, and 118 state science students. Although the statistical results must be limited to the sample, the conclusions may contribute to a better understanding of renewable and nuclear energy's social acceptance.

A remarkable limitation of the analysis can be traced back to the characteristics of the Guilfordtransformation. By reason of the results are presented on an interval-scale between 0 (least preferred) and 100 (most preferred) for each group, the comparison between groups is not feasible. A direct comparison (ratio-scale mea1sure) is available by the group level rank-sums. These values are presented as a percentage of the maximum value available.

Another limitation comes from the location. Since local availability has a significant impact on the utilization of renewables, the interpretation of the results is limited to Hungary. An international extension of the survey could allow learning about national differences.

\section{Results and discussion}

\subsection{Present and future state of renewable energy use in Hungary}

The respondents are skeptical about the present use of renewable energy sources, but they look to the future with confidence (Fig.5). The mean values of the evaluation on a 5-point scale (a higher value shows a higher agreement with the statement) are low about currently using renewable energy sources compared to other European countries. $78.7 \%$ of the respondents think that renewables are less or much less (1 and 2 values) utilized in Hungary than in other European countries. For a 10-15 years period, the proportion of this evaluation is $24.7 \%$, while $47.3 \%$ think that a European average will be reached, and $28.1 \%$ believe that Hungary will exceed it. The analysis of correlation (Table 1) points out that the better evaluation of the present use moderately and significantly correlates with the future vision. 


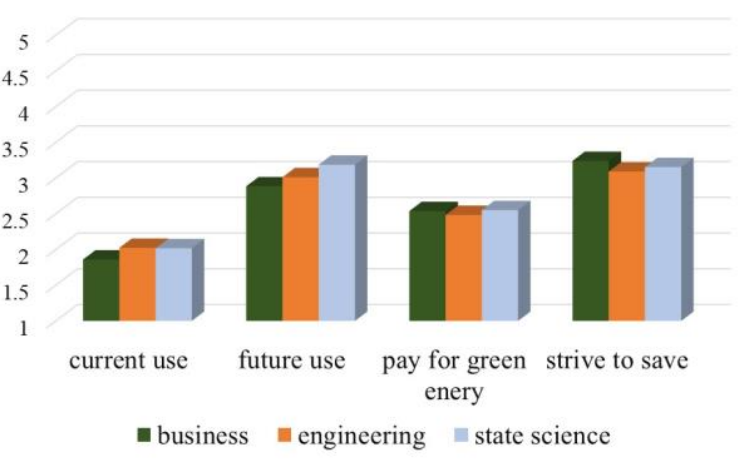

Fig.5. Mean values of student evaluations by faculties (5-point scale, a higher value means more agree with the statement)

Paying for green energy may promote the development of technologies. The respondents do not represent those who would pay more for energy if it were definitely from a 'green' source; only $19.2 \%$ market yes or certainly yes ( 4 or 5 values). At the same time, $36.9 \%$ of the respondents think that they are increasingly striving to save energy in their everyday lives. The non-parametric correlation analysis of the opinions is summarized in Table 1. The correlations can be considered as significant if the significance level (Sig.) is not higher than 0.05 . The value of the correlation coefficient shows the strength of the co-movements of the data series. Between the opinions about the present and the future use of renewable energy, there is a medium level (Correlation coefficient is 0.400 ) but significant (Significance level is 0.000) correlation that means that there is also a remarkable proportion of the students who rated the present use poor but have confidence in the future development. However, the correlation is weak among the other factors; even the results are significant. Therefore, the opinions in these questions can be considered as factors to be treated independently.

\begin{tabular}{|c|c|c|c|c|c|}
\hline & & $\begin{array}{c}\text { present } \\
\text { use }\end{array}$ & $\begin{array}{c}\text { future } \\
\text { use }\end{array}$ & $\begin{array}{l}\text { pay for } \\
\text { green } \\
\text { energy }\end{array}$ & $\begin{array}{l}\text { strive } \\
\text { to save }\end{array}$ \\
\hline \multirow[t]{2}{*}{$\begin{array}{l}\text { present } \\
\text { use }\end{array}$} & $\begin{array}{l}\text { Corr. } \\
\text { coef. }\end{array}$ & - & .400 & .093 & .081 \\
\hline & Sig. & & .000 & .093 & . 145 \\
\hline \multirow[t]{2}{*}{$\begin{array}{l}\text { future } \\
\text { use }\end{array}$} & $\begin{array}{l}\text { Corr. } \\
\text { coef. }\end{array}$ & & 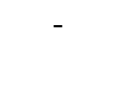 & . 149 & .189 \\
\hline & Sig. & & & .007 & .001 \\
\hline $\begin{array}{l}\text { pay for } \\
\text { green }\end{array}$ & $\begin{array}{l}\text { Corr. } \\
\text { coef. }\end{array}$ & & & - & .150 \\
\hline energy & Sig. & & & & .007 \\
\hline
\end{tabular}

Table 1. Correlation between the responses (total sample, $\mathrm{n}=328$ )
According to the research hypothesis, the impact of the faculty as a grouping factor is tested. Fig. 5 shows moderate differences between the business, engineering, and state science students. The nonparametric ANOVA test (Table 2) do not show significant differences (with 95\% confidence) since all significance levels are higher than 0.05. About striving to save the energy shows the most remarkable difference by faculties but this is not statistically proven.

\begin{tabular}{lcccc}
\hline & $\begin{array}{c}\text { present } \\
\text { use }\end{array}$ & $\begin{array}{c}\text { future } \\
\text { use }\end{array}$ & $\begin{array}{c}\text { pay for } \\
\text { green } \\
\text { energy }\end{array}$ & $\begin{array}{c}\text { strive } \\
\text { to } \\
\text { save }\end{array}$ \\
\hline Kruskal- & 3.582 & .310 & 1.087 & 5.561 \\
$\begin{array}{l}\text { Wallis H } \\
\text { df }\end{array}$ & 2 & 2 & 2 & 2 \\
Asymp. & .167 & .856 & .581 & .062 \\
Sig. & & & & \\
\hline
\end{tabular}

Table 2. Non-parametric ANOVA test results

The correlation and ANOVA test confirm the assumption on the need for a multicriteria evaluation already dealing with the acceptance of the new solutions.

\subsection{Pairwise comparison results}

Due to the limited knowledge on the subject, it is not to expect an accurate and objective evaluation of the energy sources by the citizens, but the assessment of their opinions and attitudes are essential information sources of the decision-makers. Nevertheless, citizens can express their opinion by comparing items that allow an ordinal scale measure. Pairwise comparison gives more reliable results than direct sorting in these situations [38]. The results can describe the decisive opinions (more or less preferred solutions) both on individual and group levels.

The evaluations of the respondents show a high level of consistency. According to the return, the proportion of $\mathrm{K}=1$ cases in the sample is the highest among the business students, while engineering students have a more consistent opinion about environmentally friendly nature and future role (Table 3).

\begin{tabular}{lccc}
\hline & business & engineering & $\begin{array}{c}\text { state } \\
\text { science }\end{array}$ \\
\hline Return & 82.6 & 78.7 & 72.9 \\
$\begin{array}{l}\text { Environmen- } \\
\text { tally friendly }\end{array}$ & 80.2 & 88.8 & 83.1 \\
Future role & 73.6 & 87.6 & 79.7 \\
\hline
\end{tabular}

Table 3. The proportion of entirely consistent evaluations ( $\mathrm{K}=1$ cases, $\%$ of the sub-sample) 
Table 4 summarizes the group-level rank-sums expressed as the percentage of the maximum value available $(100 \%$ is the case in which each respondent preferred the item to any other items) by the subsamples of faculties. Figures 6-8 show the results for the total sample.

\begin{tabular}{lccc}
\hline business & engineering & $\begin{array}{c}\text { state } \\
\text { science }\end{array}$ \\
\hline return & & & \\
\hline hydro & 41.8 & 46.8 & 44.8 \\
solar & 74.0 & 68.9 & 74.1 \\
nuclear & 31.8 & 30.0 & 37.2 \\
wind & 57.8 & 53.9 & 53.2 \\
biomass & 44.8 & 50.4 & 40.7 \\
\hline environmentally friendly & & \\
\hline hydro & 46.4 & 51.3 & 41.8 \\
solar & 78.1 & 76.3 & 81.1 \\
nuclear & 4.4 & 3.5 & 5.6 \\
wind & 70.1 & 69.9 & 68.6 \\
biomass & 51.0 & 49.1 & 52.8 \\
\hline future role & & & \\
\hline hydro & 27.0 & 31.7 & 26.1 \\
solar & 83.1 & 83.3 & 83.8 \\
nuclear & 43.8 & 44.6 & 50.5 \\
wind & 57.0 & 52.2 & 49.2 \\
biomass & 39.0 & 38.1 & 40.4 \\
\hline
\end{tabular}

Table 4 . Rank-sum by energy source and by faculties ( $\%$ of the maximum available value)

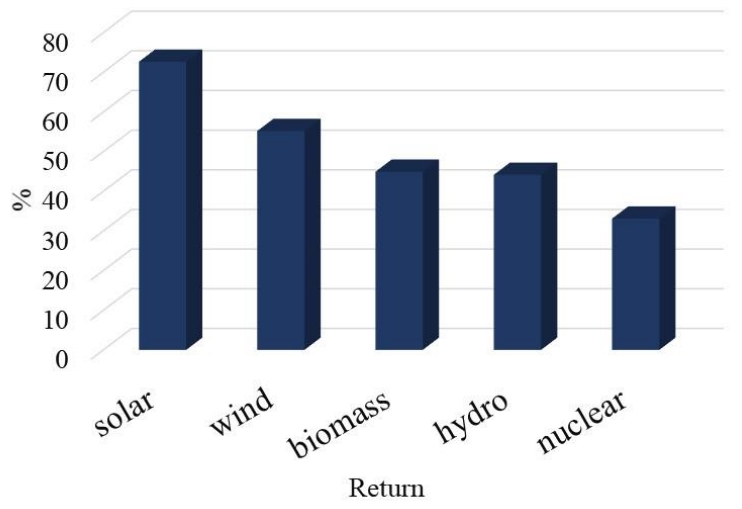

Fig.6. Preference of energy sources, return (\% of the maximum rankings)

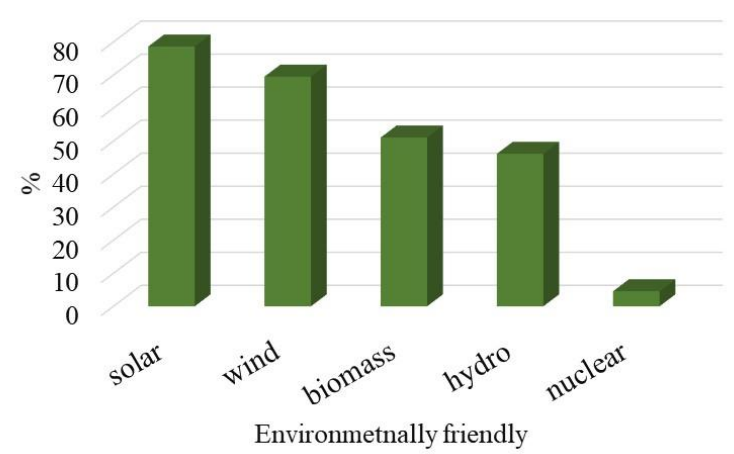

Fig.7. Preference of energy sources, environmentally friendly nature (\% of the maximum rankings)

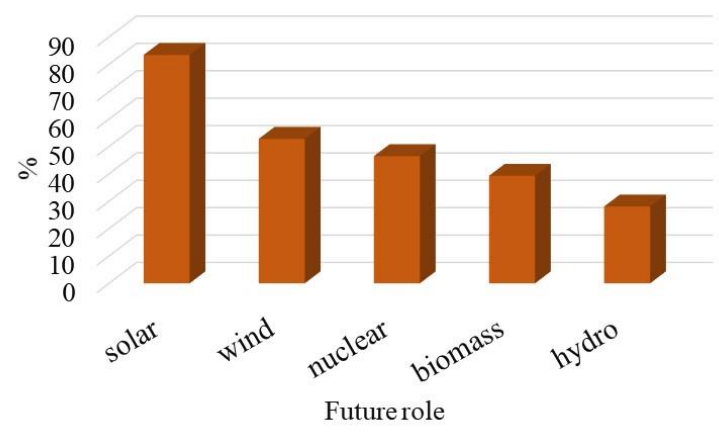

Fig.8. Preference of energy sources, future role (\% of the maximum rankings)

\begin{tabular}{lccc}
\hline & business & engineering & $\begin{array}{c}\text { state } \\
\text { science }\end{array}$ \\
\hline return & & & \\
\hline hydro & 23.8 & 43.4 & 20.2 \\
solar & 100.0 & 100.0 & 100.0 \\
nuclear & 0.0 & 0.0 & 0.0 \\
wind & 60.6 & 61.3 & 42.4 \\
biomass & 30.7 & 52.3 & 9.4 \\
\hline environmentally friendly & & \\
\hline hydro & 60.6 & 68.7 & 51.7 \\
solar & 100.0 & 100.0 & 100.0 \\
nuclear & 0.0 & 0.0 & 0.0 \\
wind & 89.3 & 91.6 & 83.3 \\
biomass & 66.1 & 66.1 & 64.4 \\
\hline future role & & & \\
\hline hydro & 0.0 & 0.0 & 0.0 \\
solar & 100.0 & 100.0 & 100.0 \\
nuclear & 29.6 & 24.1 & 41.2 \\
wind & 51.6 & 38.1 & 39.1 \\
biomass & 21.5 & 12.2 & 24.8 \\
\hline
\end{tabular}

Table 5. Guilford weights by energy sources and by faculties

Solar energy is the most preferred item in each aspect. It is followed by wind power. Nuclear energy 
is considered with the least favorable return and the least environmentally friendly solution. The latter value is remarkably low in each sub-sample, but the future role of nuclear power is rated much better. The respondents see the depreciation of hydropower in the future. Although wind-power is rated as the cleanest technology, its present and future role is rated in the middle.

The weights calculated by the Guilford-method (Table 5) point out the relative distances of the evaluations by sub-samples and aspects. The bestexpected return and the future role of solar power are unequivocal in each sub-sample. According to the environmentally friendly nature, the difference between solar (most preferred) and wind power (second preferred) is about a third compared to the difference between wind power and biomass and hydropower.

\subsection{Level of concordance}

The pairwise comparisons show some differences between the students by faculties, but the patterns do not seem to be different (Table 6, Fig.9). Kendall's coefficient of concordance for pairwise comparison (v) allows us to check the level of consensus. The indicator is expressed as a percentage of the maximum available value.

The evaluation of environmentally friendly nature shows the highest level of consensus, and there is the lowest agreement on the return. Business students' opinions are the most cohesive about the return and the future role.

\begin{tabular}{lccc}
\hline & business & engineering & $\begin{array}{c}\text { state } \\
\text { science }\end{array}$ \\
\hline return & 15.1 & 10.9 & 12.1 \\
$\begin{array}{l}\text { environmentally } \\
\text { friendly }\end{array}$ & 44.7 & 43.1 & 45.4 \\
future role & 26.8 & 22.5 & 24.9 \\
\hline
\end{tabular}

Table 6. Level of concordance by faculties (\%)

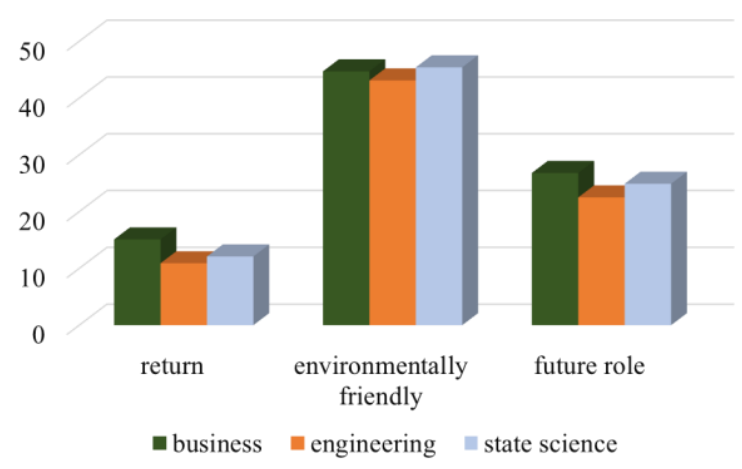

Fig.9. Level of concordance by faculties (\%)

\subsection{Interpretation of the results}

Renewable sources and nuclear energy are alternative technologies of fossil solutions. There is no one best way for the future, considering the investment cost, alternatives, environmental risks, and local availability. The technical conditions and the restrictions are objective measures of the feasibility, but legal regulations, business interests, and social acceptance cannot be ignored. Renewables are clearly preferred against nuclear power by the respondents; however, the future role precedes hydro and biomass power. Solar power is the most popular renewable, followed by wind energy is each aspect. Biomass and hydropower receive little trust from respondents.

This study contributes to a better understanding of the social aspects. Based on the responses, the Hungarian higher education students consider the utilization of renewable energy sources lags behind other European countries, but they believe in a significant change in 10-15 years. The key to changing customer behavior is rather sparing than additional expenditures on energy.

Comparing the survey results to the distribution and the trends presented in Session 2, remarkable differences appear. The dominant energy sources are undervalued by the respondents. Despite the fact that Hungary is less suitable for hydropower generation, seizing the opportunities far exceeds the respondents' expectations.

\section{Conclusion}

There is a general agreement on the need for pushing fossil energy sources back. Both renewable and nuclear energy offer alternatives; moreover, renewable energy is available in many forms. Energy policies and the related strategies must answer the questions of what, how, and when to use. These plans determine the necessary investments and impacts in the long-term, considering the benefits and the harmful impacts as well. Beyond economic interest, the social acceptance of the new technology is key to success. Social resistance can hinder the achievement of the goals. A relevant task of developing and implementing a successful energy strategy is taking the needs and opinions of the affected groups into account. This study contributes to a better understanding of personal opinions in the field. However, the results are limited, which highlights that there is a difference in the intentions of the energy strategies (professional opinions) and personal opinions. Accepting the energy policies and strategies as professional solutions, the assessment in 
this paper can be used for developing the content and form of communication to the citizens for a better understanding of the strategy, and through this, a better acceptance.

The evaluation of the respondents on renewable and nuclear power shows a cohesive picture of their environmentally friendly nature, and there is an agreement on the future role of the energy sources. However, the judgment is not is entirely consistent with the actual state of energy production. Solar power is at the heart of thinking among the respondents; it is evaluated the 'best' in all aspects. It goes beyond the possibilities and intentions of the authors and the research to make a judgment on the best energy source and technology. The results just point out the directions of the thinking.

Notwithstanding, responsible management education must include energy issues. However, the representativeness of the sample is not assured, the similar results between the business, engineering, and state science students, as well the low level of concordance on the economic aspects suggest the need for a knowledge expansion for achieving the sustainable development goals of the EU [40].

\section{References:}

[1] Högselius, P., Kaijser, A., Energy dependence in historical perspective: The geopolitics of smaller nations, Energy Policy, Vol.127, 2019, pp. 438-444. doi:10.1016/j.enpol.2018.12.025

[2] United Nations, Transforming our World: The 2030 Agenda for Sustainable Development (2015) A/RES/70/1. Available at: https://www.un.org/en/development/desa/popul ation/migration/generalassembly/docs/globalco mpact/A_RES_70_1_E.pdf (accessed on 10 August 2020)

[3] European Commission, 28/11/2018-COM (2018) 773-A Clean Planet for All-A European Strategic Long-Term Vision for a Prosperous, Modern, Competitive and Climate Neutral Economy, Available at: https://eurlex.europa.eu/legalcontent/EN/TXT/?uri=CELEX:52018DC0773 (accessed on 14 November 2019)

[4] Gaduš, J., Palková, Z., Analysis of existing and planned energy policies strategies, In: Palková, Z., Horská, E. (Eds.), Renewable Energy in Europe: Through the Policy, Education and People, Szent István University Nonprofit Publishing: Gödöllő, Hungary, 2015, pp. 8-41.

[5] Busu, M., The Role of Renewables in a LowCarbon Society: Evidence from a Multivariate Panel Data Analysis at the EU Level,
Sustainability, Vol.11, 2019, paper 5260. doi:10.3390/su11195260.

[6] Quaschning, VV., Renewable Energy and Climate Change. 2nd edition, Wiley: Hoboken, USA, 2019.

[7] National Energy Strategy 2030, Available at: https://2010-2014.kormany.hu/download/4/ f8/70000/Nemzeti\%20Energiastratégia\%20203 0\%20teljes\%20változat.pdf (accessed on 14 July 2020)

[8] Barredo, L., Mapping Renewables to the Sustainable Development Goals, Available at: https://www.unsdsn.org/news/2018/02/27/map ping-renewables-to-the-sustainabledevelopment-goals (accessed on 17 August 2020)

[9] Skamp, K., Boyes, E., Stanisstreet, M., Rodriguez, M., Malandrakis, G., Fortner, R., Kilinc, A., Taylor, N., Chhokar, K., Dua, S., Ambusaidi, A., Cheong, I., Kim, M, Yoon H.G., Renewable and Nuclear Energy: An International Study of Students' Beliefs about, and willingness to act, in relation to two energy production Scenarios, Research in Science Education, Vol.49, 2019, pp. 295-329. doi:10.1007/s11165-017-9622-6

[10] Deutsch, N., The changing role of nuclear power in the European Union: Reflections from official scenarios released before and after the Fukushima Daiichi accident, Theory Methodology Practice. Club Economics in Miskolc, Vol.13, No.1, 2017, pp.17-36. doi:10.18096/TMP.2017.01.03

[11] Awadalla, M., Abdien, A.K., Rashad, S.M., Ahmed, A., Al Abri, D., Classification of Faults in Nuclear Power Plant, WSEAS Transactions on Systems, Vol.13, 2014, pp. 274-284.

[12] Dawson, J.I., Darst, R.G., Meeting the challenge of permanent nuclear waste disposal in an expanding Europe: Transparency, trust and democracy, Environmental Politics, Vol.15, No.4, 2006, pp. 610-627. doi:10.1080/09644010600785226

[13] Hocke, P., Renn, O., Concerned public and the paralysis of decision-making: Nuclear waste management policy in Germany, Journal of Risk Research, Vol.12 No.7-8, 2009, pp. 921-940.

[14] Wilkins, G., Technology Transfer for Renewable Energy: Overcoming Barriers in Developing Countries, Earthscan Publication: London, UK, 2002.

[15] Raven, R.P., Joliver, E., Mourik, R.M., Feenstra, Y.C., ESTEEM: Managing societal acceptance in new energy projects A toolbox method for project managers. Technological Forecasting 
and Social Change, Vol.76, No.7, 2009, pp 963-977. doi:10.1016/j.techfore.2009.02.005

[16] Sütterlin, B., Siegrist, M., Public acceptance of renewable energy technologies from an abstract versus concrete perspective and the positive imagery of solar power, Energy Policy, Vol.106, pp. 365-366. doi:10.1016/j.enpol.2017.03.061

[17] Gil Vera, V. D., Development of a Structural Equation Model for Studying the Renewable Energy Acceptance in Universitary Students. International Journal of Energy and Environment, Vol.13, 2019, pp. 22-25.

[18] Svigelj, A., Pseudo measurements based on smart meters prosumer's characterization for distribution system state estimation. International Journal of Circuits, Systems and Signal Processing, Vol.12, 2018, pp. 466-476.

[19] Batel, S., Devine-Wright, P., Tangeland, T., Social acceptance of low carbon energy and associated infrastructures: A critical discussion, Energy Policy, Vol.58, 2013, pp. 1-5. doi:10.1016/j.enpol.2013.03.018

[20] Zoellner, J., Schweizer-Ries, P., Wemheuer, C., Public acceptance of renewable energies: Results from case studies in Germany, Energy Policy, Vol.36, 2008, pp. 4136-4141. doi:10.1016/j.enpol.2008.06.026

[21] Wüstenhangen, R., Wolsnik, M., Bürer, M.J., Social acceptance of renewable energy innovation: An introduction to the concept, Energy Policy, Vol.35, 2007, pp. 2683-2691. doi:10.1016/j.enpol.2006.12.001

[22] Sequeira, T.N., Santos, M.S., Renewable energy and politics: A systematic review and new evidence. Journal of Cleaner Production, Vol.192, 2018, pp. 553-568. doi:10.1016/j.jclepro.2018.04.190

[23] Berényi, L., Birkner, Z., Deutsch, N., A Multidimensional Evaluation of Renewable and Nuclear Energy among Higher Education Students, Sustainability, Vol.12, No.4, 2020, paper 1449. doi:10.3390/su12041449

[24] Tortop, H.S., Awareness and misconceptions of high school students about renewable energy resources and applications: Turkey case, Energy Education Science and Technology Part B: Social and Educational Studies, Vol.4, No.3, 2012, pp. 1829-1840.

[25] Rodgers, V.L., Pitching Environmental Science to Business Majors: Engaging Students in Renewable Energy Choices, Journal of College Science Teaching, Vol.43, No.5, 2014, pp. 2832.

[26] Çelikler, D., Aksan, Z., The opinions of secondary school students in Turkey regarding renewable energy, Renewable Energy, Vol.75, 2015 , doi:10.1016/j.renene.2014.10.036 pp.649-653,

[27] Assali, A., Khatib, T., Najjar, A., Renewable energy awareness among future generation of Palestine, Renewable Energy, Vol.136, 2019, pp.254-263. doi:10.1016/j.renene.2019.01.007

[28] Karasmanaki, E., Tsantopoulos, G., Exploring future scientists' awareness about and attitudes towards renewable energy sources, Energy Policy, Vol.131, 2019, pp.111-119. doi:10.1016/j.enpol.2019.04.032

[29] McNeal, K.S., Spry, J.M., Mitra, R., Tipton, J.L, Measuring Student Engagement, Knowledge, and Perceptions of Climate Change in an Introductory Environmental Geology Course, Journal of Geoscience Education, Vol.62, No.4, 2014, pp. 655-657. doi:10.5408/13-111.1

[30] DIRECTIVE 2009/28/EC OF THE EUROPEAN PARLIAMENT AND OF THE COUNCIL of 23 April 2009 on the promotion of the use of energy from renewable sources and amending and subsequently repealing Directives 2001/77/EC and 2003/30/EC, Available at: https://eurlex.europa.eu/legal-

content/EN/TXT/HTML/?uri=CELEX:32009L 0028\&from=EN (accessed on 11 August 2020)

[31] EUROSTAT, Energy statistical datasheets for the EU countries, Available at: https://data.europa.eu/euodp/en/data/dataset/inf ormation-on-energy-markets-in-eu-countrieswith-national-energy-profiles (accessed on 10 August 2020)

[32] Hungarian Central Statistical Office, Share of electricity from renewable energy sources and waste (2000-2018), Available at: https://www.ksh.hu/docs/hun/xstadat/xstadat_e ves/i_ui011a.html (accessed on: 10 August 2020)

[33] Hungarian Central Statistical Office, Production of primary renewable energy sources by energy source (2000-2018), Available at: https://www.ksh.hu/docs/hun/xstadat/xstadat_e ves/i_ui012a.html (accessed on 10 August 2020)

[34] Bajaj, S., Sandhu, K.S., Effect of site and size of wind turbine on its economic operation. International Journal of Circuits, Systems and Signal Processing, Vol.13, 2019, pp. 237-242.

[35] Nemes, C., Munteanu, F., The wind energy system performance overview: capacity factor vs. technical efficiency. International Journal of Mathematical Models and Methods in Applied Sciences, Vol.5, No.1, 2011, pp.159-166.

[36] Sağlam S., Meteorological Parameters Effects on Solar Energy Power Generation, WSEAS 
Transactions on Circuits and System, Vol.10, No.9, 2010, pp. 637-649.

[37] Ross, R.T., Optimum orders for the presentation pairs in the method of paired comparisons, Journal of Education Psychology, Vol.25, 1934, pp. 375-382.

[38] Kindler J., Papp, O., Komplex rendszerek vizsgálata: Összemérési módszerek, Müszaki Könyvkiadó: Budapest, Hungary, 1978.

[39] Wagner W.E., Using IBM ${ }^{\circledR}$ SPSS ${ }^{\circledR}$ Statistics for Research Methods and Social Science Statistics. 7th edition, SAGE: London, UK, 2019.

[40] Weybrecht, G., From challenge to opportunity Management education's crucial role in sustainability and the Sustainable Development Goals - An overview and framework. The International Journal of Management Education, Vol.15, No.2, 2017, pp. 84-92. doi:10.1016/j.ijme.2017.02.008

\section{Contribution of individual authors to the creation of a scientific article (ghostwriting policy)}

László Berényi designed the survey and methodology, managed data collection, participated the analysis and writing (original draft) the paper.

Nikolett Deutsch carried out literature review, managed statistical analysis, participated the analysis and writing (review and editing) the paper.

\section{Sources of funding for research presented in a scientific article or scientific article itself \\ This research received no sources of funding.}

\section{Creative Commons Attribution License 4.0 (Attribution 4.0 International, CC BY 4.0)}

This article is published under the terms of the Creative Commons Attribution License 4.0

https://creativecommons.org/licenses/by/4.0/deed.en_US 